\title{
Meningkatkan Kemampuan Membaca Permulaan Menggunakan Media Snader Game
}

\author{
Risah Arijani \\ risaharijani@gmail.com \\ PPPTK Seni dan Budaya
}

\begin{abstract}
Abstrak
Upaya untuk membantu anak usia dini agar tumbuh dan berkembang sesuai dengan tingkat perkembangannya adalah dengan memberikan stimulasi yang tepat dan aman khususnya saat mengajarkan pembaca permulaan. Fakta riil di lapangan menunjukkan bahwa sebagian orang tua dan pendidik masih terus melakukan praktik-praktik pengajaran yang memaksa anak. Sebagian orang tua masih memilih antara bermain dan belajar, sehingga ada pengaturan waktu bermain dan belajar. Belajar diartikan sebagai aktivitas produktif dan bermain diartikan sebagai aktivitas tak produktif. Padahal melalui bermain itulah anak bisa belajar. Salah satu kegiatan bermain sambil belajar adalah melalui snader game. Bagi anak-anak media pembelajaran permainan akan sangat menyenangkan dan mudah untuk dipahami, karena media pembelajaran dalam bentuk snader game mampu melatih kemampuan membaca permulaan anak dan memotivasi anak untuk belajar dan bersosialisasi.
\end{abstract}

Kata Kunci: kemampuan membaca permulaan, snader game

\section{Abstract}

Efforts to help young children to grow and develop in accordance with the level of development is to provide appropriate stimulation and safe especially when teaching beginning readers. The real facts on the ground indicate that the majority of parents and educators are still doing the teaching practices that force children. Some parents still choose between play and learning, so no time to play and learning settings. Learning is defined as a productive activity and play is defined as non-productive activity. Yet through play that children can learn. One of the activities while learning to play the game is through snader. For children learning media game will be very fun and easy to understand, as a medium of learning in the form of games snader able to practice beginning reading skills of children and motivate children to learn and socialize.

Keywords: beginning reading skills, snader game

\section{Pendahuluan}

Pendidikan di tingkat Playgroup atau Kelompok Bermain (KB) dan Taman Kanak-Kanak (TK) merupakan salah satu bentuk Pendidikan Anak Usia Dini yaitu anak yang berusia dua sampai dengan enam tahun. Maimunah (2010: 17) mendefinisikan anak usia dini sebagai anak yang masuk dalam rentang usia 0-6 tahun. Sementara itu, menurut kajian ilmu PAUD dan penyelenggaraannya di beberapa negara, PAUD dilaksanakan sejak usia 0-8 tahun. Pendidikan Taman Kanak-Kanak memiliki peran yang sangat penting untuk mengembangkan kepribadian anak serta mempersiapkan mereka untuk memasuki jenjang pendidikan selanjutnya. Dengan kata lain, 
Pendidikan usia dini khususnya $\mathrm{KB}$ dan TK sangat mengutamakan pendidikan yang berpusat pada anak. Dalam UndangUndang Sistem Pendidikan Nasional (2003: 4) pada pasal 1 ayat (14) menyatakan bahwa pendidikan anak usia dini adalah suatu upaya pembinaan yang ditujukan kepada anak sejak lahir sampai dengan usia enam tahun yang dilakukan melalui pemberian rangsangan pendidikan untuk membantu pertumbuhan dan perkembangan agar anak memasuki pendidikan lebih lanjut.

Anak usia dini berada dalam tahap pertumbuhan dan perkembangan yang paling pesat, baik fisik maupun mental (Suyanto, 2005: 5). Maka tepatlah bila dikatakan bahwa usia dini adalah usia emas (golden age), di mana anak sangat berpotensi mempelajari banyak hal dengan cepat. Sebagai lembaga pendidikan prasekolah, tugas utama Kelompok Bermain (KB) dan Taman Kanak-Kanak (TK) adalah mempersiapkan anak dengan memperkenalkan berbagai pengetahuan, sikap perilaku, keterampilan dan intelektual agar dapat melakukan adaptasi dengan kegiatan belajar yang sesungguhnya di Sekolah Dasar. Persoalan membaca, menulis, dan berhitung atau calistung memang merupakan fenomena tersendiri. Kini fenomena tersebut semakin hangat dibicarakan orang tua yang memiliki anak usia dini akan ke khawatiran anak-anaknya tidak mampu mengikuti pelajaran di Sekolah Dasar jika sedari awal belum dibekali ketrampilan calistung. Hal ini membuat para orang tua akhirnya sedikit memaksa sang anak untuk belajar calistung, khususnya membaca.

Selama ini pendidikan anak usia dini didefinisikan sebagai persiapan untuk memasuki masa sekolah yang dimulai di jenjang Sekolah Dasar. Oleh karena itu kegiatan yang dilakukan di Kelompok Bermain (KB) dan Taman Kanak-Kanak (TK) hanyalah bermain dengan menggunakan alat-alat bermain edukatif. Pelajaran membaca, tidak diperkenankan di tingkat Taman Kanak-Kanak, kecuali pengenalan huruf-huruf, itupun dilakukan setelah anak-anak memasuki TK B.

Perkembangan terakhir hal itu menimbulkan sedikit masalah, karena ternyata pelajaran di kelas satu Sekolah Dasar sulit diikuti jika anak-anak lulusan Taman Kanak-Kanak belum mendapatkan pelajaran membaca. Karena tuntutan itulah akhirnya banyak Taman Kanak-Kanak yang secara mandiri mengupayakan pelajaran membaca bagi anak-anaknya. Berbagai metode mengajar dipraktikkan, dengan harapan bisa membantu anak-anak menguasai keterampilan membaca sebelum masuk Sekolah Dasar. Beberapa anak mungkin berhasil menguasai keterampilan tersebut, namun banyak pula diantaranya yang masih mengalami kesulitan.

Upaya untuk membantu anak usia dini agar tumbuh dan berkembang sesuai dengan tingkat perkembangannya perlu diberikan stimulasi yang tepat dan aman khususnya mengajarkan pembaca permulaan. Fakta riil di lapangan menunjukkan bahwa sebagian orang tua dan pendidik masih terus melakukan praktik-praktik pengajaran yang memaksa anak, sebagaimana dinyatakan Vygotsky (Musfiroh, 2009: 2) bahwa cara-cara pemaksaan dalam pembelajaran tidak akan membuat anak memperoleh ilmu, tetap justru akan kehilangan masa-masa emas dan proses pemerolehan mental. Masa anak-anak merupakan masa-masa bermain sekaligus masa-masa emas untuk menerima berbagai rangsangan. Pada masa ini, anak dapat diberi berbagai materi asalkan sesuai dengan perkembangan mereka, yakni melalui bermain, sebagian orang tua masih memilih antara bermain dan belajar, sehingga ada pengaturan waktu bermain dan belajar. Belajar diartikan sebagai aktivitas produktif dan bermain diartikan sebagai aktivitas tak produktif. Padahal melalui bermain itulah anak bisa belajar.

Salah satu kegiatan bermain sambil belajar adalah melalui snader game. Bagi anak-anak media pembelajaran permainan 
akan sangat menyenangkan dan mudah untuk dipahami, karena media pembelajaran dalam bentuk snader game mampu melatih kemampuan membaca permulaan anak dan memotivasi anak untuk belajar dan bersosialisasi. Inilah yang membuat peneliti memiliki gagasan menjadikan snader game sebagai media pembelajaran membaca permulaan untuk anak Playgroup dan TPA agar anak-anak dapat belajar sambil bermain.

Media snader game merupakan modifikasi permainan ular tangga. Snader game adalah sebuah plastik flexy bergambar, ukuran papan permainan $3 \mathrm{~m}$ x $4 \mathrm{~m}$, yang terdiri atas kotak-kotak yang berjumlah 26 buah sesuai dengan jumlah alfabet, masing-masing kotak berukuran. $50 \mathrm{~cm} \times 50 \mathrm{~cm}$. Tiap kotak diberi nomor urut mulai dari nomor 1 sampai dengan 26. Kotak-kotak tertentu berisi gambar yang mengandung pesan atau perbuatan. Ada pesan atau perbuatan baik, ada yang buruk. Pesan atau perbuatan baik diganjar dengan kenaikan ke kotak yang lebih tinggi lewat tangga, sedangkan pesan atau perbuatan buruk dihukum dengan penurunan ke kotak lebih rendah melewati ular.

Media snader game diharapkan dapat digunakan sebagai alat bantu media pembelajaran yang dapat membantu proses belajar. Seperti disampaikan oleh Hamalik (Arsyad, 2006: 16), bahwa pemakaian media dalam proses pembelajaran dapat membangkitkan keinginan dan minat yang baru, membangkitkan motivasi, memberikan rangsangan kegiatan belajar, bahkan membawa pengaruh-pengaruh psikologis pada anak. Media akan dapat menarik minat anak dan akhirnya berkonsentrasi untuk belajar dan memahami pelajaran.

\section{Kemampuan Membaca Permulaan}

Salah satu prinsip perkembangan menyatakan bahwa perkembangan merupakan hasil proses kematangan dan belajar. Proses kematangan adalah terbukanya karakteristik yang secara potensial ada pada individu dan berasal dari warisan genetik (Hurlock, 199: 28). Beberapa proses belajar berasal dari latihan atau pengulangan suatu tindakan yang nantinya menimbulkan perubahan dalam perilaku (Hurlock, 199: 29). Kematangan menentukan siap atau tidaknya seseorang untuk belajar, karena betapapun banyaknya rangsangan yang diterima anak, mereka tidak dapat belajar dan menghasilkan perubahan perilaku sampai mereka dinyatakan siap menurut taraf perkembangannya. Havighurst (Hurlock, 1991: 30) menamakan kondisi kesiapan belajar yang ditentukan oleh kematangan ini sebagai teachable moment, atau saat yang tepat bagi anak untuk "diajar".

Menurut Ahmad Susanto (201: 83), membaca pada hakekatnya sudah dapat diajarkan pada balita, namun menurut penelitian Glen lebih efektif diberikan pada usia empat tahun dari pada usia lima tahun. Bahkan, menurutnya, usia tiga tahun lebih mudah dari pada empat tahun. Jelasnya, makin kecil mudah untuk belajar, namun tentu semakin kecil usianya, akan sangat menuntut kesabaran pada orang tua atau guru yang mengajarkannya.

Pernyataan di atas memberi makna bahwa kematangan sangat berperan dalam menentukan waktu yang tepat hingga anak dinyatakan siap untuk belajar membaca. Anak yang berada pada masa peka untuk belajar membaca akan dengan mudah menerima dan menanggapi rangsangan yang diberikan padanya dalam bentuk huruf, suku kata, kata, atau kalimat. Anak pun akan cepat memberi respon tiap kali stimulus yang sama muncul, dan sebagai hasilnya anak akan menunjukkan perubahan perilaku sebagai indikator keberhasilan proses belajarnya, yang dalam hal ini berarti anak menguasai kemampuan-kemampuan yang diperlukan dalam membaca.

Munandar

(1999: 17), mendefinisikan kemampuan merupakan daya untuk melakukan suatu tindakan sebagai hasil dari pembawaan dan latihan. Artinya seseorang dapat melakukan 
sesuatu karena adanya kemampuan yang dimilikinya atau potensi seseorang yang merupakan bawaan sejak lahir serta dipermatang dengan adanya pembiasaan dan latihan, sehingga ia mampu melakukan sesuatu. "Membaca" berarti melihat serta memahami isi dari apa yang tertulis, atau mengeja dan melafalkan apa yang tertulis.

Selanjutnya Poerwadarminta (1999: 623), bahwa "kemampuan" berarti kesanggupan atau kecakapan. Kemampuan adalah kesanggupan atau kecakapan untuk menguasai sesuatu yang sedang dihadapi. Dalam pembelajaran bahasa kemampuan membaca sangat diperlukan dan harus dimiliki oleh seseorang karena kemampuan membaca merupakan dasar untuk menguasai berbagai bidang studi. Jika anak pada usia sekolah permulaan tidak segera memiliki kemampuan membaca, maka ia akan mengalami banyak kesulitan dalam mempelajari berbagi bidang studi pada kelas-kelas berikutnya.

\section{Broto (Mulyono Abdurahman, 2012: 158) mengemukakan bahwa} membaca bukan hanya mengucapkan bahasa tulisan atau lambang bunyi bahasa, melainkan juga menanggapi dan memahami isi bahasa tulisan. Dengan demikian, membaca pada hakekatnya merupakan suatu bentuk komunikasi tulis. Sementara menurut Hartati (Ahmad Susanto, 2011: 84), membaca pada hakekatnya adalah kegiatan fisik dan mental untuk menemukan makna dari tulisan, walaupun dalam kegiatan ini terjadi pengenalan huruf-huruf. Membaca dikatakan sebagai kegiatan fisik karena pada saat membaca bagian-bagian tubuh khususnya mata membantu melakukan proses membaca. Aktivitas mental mencakup ingatan dan pemahaman. Orang dapat membaca dengan baik jika mampu melihat huruf-huruf dengan jelas, mampu menggerakkan mata secara lincah, mengingat simbol bahasa dengan tepat dan memiliki penalaran yang cukup untuk memahami bacaan.
Dari berbagai pengertian di atas dapat disimpulkan bahwa yang dimaksud dengan kemampuan membaca permulaan aktivitas kompleks yang mencakup fisik dan mental mengacu pada kecakapan. Kecakapan yang dimaksud adalah kemampuan atau kesanggupan siswa membaca dengan lafal, intonasi yang jelas, dan benar. Pengajaran membaca permulaan lebih ditekankan pada pengembangan kemampuan dasar membaca. Siswa dituntut untuk dapat menyuarakan huruf, suku kata, kata dan kalimat yang disajikan dalam bentuk tulisan ke dalam bentuk lisan.

\section{Tujuan Membaca}

Membaca hendaknya mempunyai tujuan, karena seorang yang membaca dengan suatu tujuan, cenderung lebih memahami dibandingkan dengan orang yang tidak mempunyai tujuan. Tujuan membaca pada anak usia dini menurut Brewer (Ahmad Susanto, 2011: 87), adalah tujuan yang merupakan persiapan membaca, karena pada saat ini belum terjadi kegiatan membaca yang sebenarnya, karena kegiatan ini baru bagian awal dari kegiatan membaca. Sejalan dengan pemikiran tersebut, Gordan dan Brown (Ahmad Susanto, 2011: 87) dalam mengajarkan keterampilan membaca perlu dipersiapkan hal-hal yang berkaitan dengan perbendaharaan kata, keingintahuan anak tentang baca, dan perbedaan visual dalam membelajarkan keterampilan membaca.

Tujuan pengajaran membaca adalah agar anak dapat membaca katakata dan kalimat sederhana dengan benar dan tepat, dalam mengajarkan membaca hendaknya memberikan berbagai kegiatan yang berkaitan dengan kesiapan membaca yaitu: mengenalkan anak pada huruf-huruf dalam abjad sebagai tanda suara atau tanda bunyi, melatih ketrampilan anak untuk mengubah huruf-huruf dalam kata menjadi suara, dan pengetahuan huruf-huruf dalam abjad dan ketrampilan menyuarakan wajib untuk dapat dipraktikkan dalam waktu singkat ketika anak belajar membaca lanjut. 
Tahapan Mengajarkan Membaca

Membaca merupakan proses yang kompleks. Proses ini melibatkan sejumlah kegiatan fisik dan mental. Glen (Ahmad Susanto, 2011: 84) menjelaskan, bahwa mengajar membaca harus dimulai dengan mengeja, dimulai dengan pengenalan huruf kemudian mengenal suku kata, barulah mengenal kata dan akhirnya kalimat. Belajar membaca dan menulis merupakan hal yang sangat sulit bagi anak karena anak harus belajar huruf dan bunyi.

$$
\text { Sementara itu Mercer }
$$

(Abdurrahman, 2012: 159-161) membagi tahapan membaca menjadi lima, yaitu:

1. Kesiapan membaca

Tahap perkembangan kesiapan membaca mencakup rentang waktu dari sejak dilahirkan hingga pelajaran membaca diberikan.

2. Membaca permulaan

Tahap membaca permulaan umumnya dimulai sejak anak masuk kelas satu SD, yaitu pada saat berusia sekitar enam tahun. Meskipun demikian, ada anak yang sudah belajar membaca lebih awal dan ada pula yang baru belajar membaca pada usia tujuh atau delapan tahun.

3. Ketrampilan membaca cepat

Ketrampilan membaca cepat atau membaca lancar umumnya terjadi pada saat anak-anak duduk di kelas dua atau kelas tiga SD.

4. Membaca luas

Tahap membaca luas umumnya terjadi pada saat anak-anak telah duduk di kelas empat atau lima SD. Pada tahap ini anak-anak gemar dan menikmati sekali membaca.

5. Membaca yang sesungguhnya

Tahap membaca yang sesungguhnya umumnya terjadi ketika anak-anak sudah duduk di SLTP dan berlanjut hingga dewasa. Pada tahap ini anakanak tidak lagi belajar membaca tetapi membaca untuk belajar.
Karakteristik mengajarkan baca tulis menurut Tadkiroatun Musfiroh (2009: 28) dikategorikan ke dalam enam tahapan yaitu:

1. Tahapan diferensiasi

Pada tahap ini anak memperhatikan tulisan dan membedakannya dengan gambar. Anak dapat menyebutkan gambar sebagai gambar dan tulisan sebagai tulisan.

2. Tahapan membaca pura-pura

Anak membaca tulisan tanpa mempedulikan informasi visual yang ada. Anak benar-benar menentukan sendiri kata-kata yang ingin diucapkan tanpa mempedulikan tulisan yang ada. Belum ada korespondensi antara apa yang diucapkan (dibaca) anak dengan bahan bacaan.

3. Tahapan membaca gambar

Anak memperhatikan gambar tandatanda visual seperti gambar tetapi belum menguasai simbol. Anak membaca dengan melihat gambar, membaca label dengan memperhatikan barang dan gambar. Anak menjabarkan gambar atau informasi visual lain dalam bentuk satu kalimat atau lebih.

4. Tahapan membaca acak

Pada tahap membaca acak anak sudah memperhatikan simbol.

5. Tahapan lepas landas

Anak dapat membaca dengan mengeja kata-kata, dan anak dapat menggabungkan huruf menjadi suku kata.

6. Tahapan independen

Pada tahap ini anak memahami apa yang dibaca. Sudah ada lagu kalimat (koma, titik) dan nada yang cepat. Anak sudah menguasai komponen tanda baca, dan makna teks juga sudah diperoleh.

\section{Kemampuan Membaca Permulaan Anak Usia Dini}

Menurut (Ahmad Susanto, 2011: 83) Membaca permulaan ialah membaca yang diajarkan secara terprogram pada anak prasekolah. Membaca sudah dapat 
diajarkan pada balita Anak prasekolah adalah anak berusia 3-6 tahun. Biasanya mengikuti program prasekolah atau kindergarten menurut Biechler dan Snowman (Patmonodewo, 2003: 19). Sedangakan di Indonesia, umumnya anak mengikuti program Tempat Penitipan Anak (TPA) usia 3 bulan -5 tahun, dan Kelompok Bermain (KB) usia 3-4 tahun, sedangkan pada usia 4-6 tahun biasanya anak mengikuti program Taman KanakKanak.

Tzu (Ahmad Susanto, 201: 84) mengatakan bahwa pengertian membaca adalah menerjemahkan simbol (huruf) ke dalam suara yang dikombinasi dengan kata-kata. Kata-kata disusun sehingga kita dapat belajar memahaminya, dan dapat membaca. Sehubungan dengan hal tersebut, maka bahan-bahan untuk membaca permulaan harus sesuai dengan bahasa dan pengalaman anak. Belajar bahasa, dan membaca bagi anak terjadi ketika anak memilih, mengamati, berpikir, berkata, bermain, membaca, mendengarkan dengan anak lain dan dengan orang dewasa yang memahami bagaimana mendorong kegiatan tersebut.

Piaget (Suyanto, 2005: 55) menyatakan anak berada pada tahap perkembangan kognitif preoperasional 2-7 tahun. Pada tahap ini anak mulai menunjukkan proses berpikir yang lebih jelas. Ia mulai mengenali beberapa simbol dan tanda termasuk bahasa dan gambar. Penguasaan bahasa anak pada tahap ini sudah sistematis, anak sudah mampu melakukan permainan simbolis, imitasi, serta mampu mengantisipasi keadaan yang akan terjadi pada waktu mendatang. Bahasa terdiri dari berbagai simbol yang dapat terungkap secara lisan maupun tulisan. Pemerolehan bahasa terjadi pada subtahap pemikiran simbolik tahap praoperasional tersebut, sehingga menurut Piaget, bahasa merupakan hasil dari perkembangan intelektual secara keseluruhan, dan sebagai bagian dari kerangka fungsi simbolik.
Anak usia dini memiliki potensi yang terpendam untuk menjadi pembaca yang baik. Tahap perkembangan yang memungkinkan mereka mengerti simbolsimbol dalam bahasa memberi kesempatan untuk cepat belajar dan mengasah ketajaman berpikir. Selain itu, anak-anak sebagai pembaca permulaan umumnya memiliki kesadaran fonemis yang cukup baik dan sangat berguna dalam proses membaca. Karena itu, diperlukan adanya pemilihan metode yang tepat dengan harapan anak dapat belajar membaca dengan efektif, memanfaatkan segala potensinya, dan merasa nyaman dalam belajar menggunakan metode yang memperhatikan kebutuhan belajar mereka, sehingga kegiatan ini menjadi kegiatan yang menyenangkan. Jika anak sudah memiliki rasa senang membaca, akan lebih mudah untuk dibimbing dalam kegiatan belajar membaca yang lebih kompleks. Kegemaran membaca ini akan lebih tepat bila sudah ditanamkan sejak dini, sehingga kegiatan membaca bukan menjadi suatu beban, melainkan suatu kebutuhan. Pembelajaran membaca pra sekolah harus benar-benat dilaksanakan dengan sistematis, artinya dengan kebutuhan, minat, perkembangan, dan karakteristik anak. Proses pembelajaran, media pembelajaran yang digunakan, harus diperhatikan, dan lingkungan belajar harus kondusif.

\section{Proses Pembelajaran Membaca}

Dalam pembelajaran membaca permulaan ada empat faktor yang mempengaruhi. Menurut Lamb dan Arnold (Farida Rahim, 2008: 16), faktor yang mempengaruhi membaca permulaan adalah:

1. Faktor Fisiologis

Faktor fisiologis mencakup kesehatan fisik, pertimbangan neurologis, dan jenis kelamin. Kelelahan juga merupakan kondisi yang tidak menguntungkan bagi anak untuk belajar, khususnya belajar membaca. 
2. Faktor Intelektual

Secara umum, intelegensi anak tidak sepenuhnya mempengaruhi berhasil atau tidaknya anak dalam membaca permulaan. Faktor metode mengajar guru, prosedur, dan kemampuan guru juga turut memengaruhi kemampuan membaca permulaan anak.

3. Faktor Lingkungan

Faktor lingkungan juga mempengaruhi kemajuan kemampuan membaca

siswa. Faktor lingkungan itu mencakup: (1) latar belakang dan pengalaman siswa di rumah; dan (2) sosial ekonomi keluarga siswa.

4. Faktor Psikologis

Faktor lain yang juga mempengaruhi kemajuan kemampuan membaca anak adalah faktor psikologis. Faktor ini mencakup (1) motivasi; (2) minat; dan (3) kematangan sosial, emosi, dan penyesuaian diri.

Abdurrahman (2012: 171-174) mengemukakan metode pengajaran membaca bagi anak pada umumnya, antara lain:

1. Metode membaca dasar

Metode membaca dasar pada umumnya menggunakan pendekatan eklektik yang menggabungkan berbagai prosedur untuk mengajarkan kesiapan, perbendaharaan kata, mengenal kata, pemahaman, dan kesenangan membaca. Metode ini umumnya dilengkapi rangkaian buku yang disusun dari taraf sederhana hingga taraf yang lebih sukar, sesuai dengan kemampuan atau tingkat kelas anak-anak.

2. Metode fonik

Metode fonik menekankan pada pengenalan kata melalui proses mendengarkan bunyi huruf. Pada mulanya anak diajak mengenal bunyi -bunyi huruf, kemudian mensintesiskannya menjadi suku kata, dan kata. Bunyi huruf dikenalkan dengan mengaitkannya dengan kata benda, misalnya huruf "a" dengan gambar "ayam". Dengan demikian, metode ini lebih bersifat sintesis daripada analitis.

3. Metode linguistik

Metode linguistik didasarkan atas pandangan bahwa membaca adalah proses memecahkan kode atau sandi yang berbentuk tulisan menjadi bunyi yang sesuai dengan percakapan. Anak diberikan suatu bentuk kata yang terdiri dari konsonan-vokal atau konsonan-vokal-konsonan, seperti "bapak" atau "lampu". Kemudian anak diajak memecahkan kode tulisan itu menjadi bunyi percakapan. Dengan demikian, metode ini lebih bersifat analitik dari pada sintetik.

4. Metode SAS (Struktural Analitik Sintetik)

Metode ini pada dasarnya merupakan perpaduan antara metode fonik dan linguistik. Perbedaannya adalah jika di dalam metode linguistik kode tulisan yang dipecahkan berupa kata,

- di dalam SAS berupa kalimat pendek yang utuh. Metode ini berdasarkan asumsi bahwa pengamatan anak mulai dari keseluruhan (gestalt) dan kemudian ke bagian-bagian.

5. Metode alfabetik

Metode ini menggunakan dua langkah, yaitu memperkenalkan kepada anak berbagai huruf alfabetik dan kemudian merangkaikan hurufhuruf tersebut menjadi suku kata, kata, dan kalimat.

6. Metode pengalaman bahasa

Metode ini terintegrasi pada perkembangan anak dalam ketrampilan mendengarkan, bercakapcakap, dan menulis. Bahan bacaan yang digunakan didasarkan atas pengalaman anak.

Pembelajaran membaca yang dimaksud disini ialah proses pembelajaran untuk menimbulkan kebiasaan dan minat membaca pada anak. Proses pembelajaran ini perlu diketahui, terutama bagi tingkat dasar, agar anak memperoleh pengalaman belajar yang baik dan menyenangkan 
dalam pembelajaran membaca permulaan. Maka pembelajaran untuk anak usia dini harus benar-benar dilaksanakan dengan sistematis, artinya sesuai dengan kebutuhan, minat, perkembangan, dan karakteristik anak. Proses pembelajaran, alat-alat permainan atau media pembelajaran yang digunakan, harus diperhatikan, dan lingkungan belajar harus kondusif. Hal ini sangat penting, sebab bila anak mengalami kegagalan pada periode ini, akan berpengaruh terhadap kemampuan berbahasa anak.

Berdasarkan kondisi tersebut, bagaimana agar anak tertarik membaca, sehingga kegiatan ini menjadi kegiatan yang menyenangkan. Jika. anak sudah memiliki rasa senang membaca, akan lebih mudah untuk dibimbing dalam kegiatan belajar membaca yang lebih kompleks. Kegemaran membaca ini akan lebih tepat bila sudah ditanamkan sejak dini, sehingga kegiatan membaca bukan menjadi suatu beban, melainkan suatu kebutuhan.

\section{Media Snader Game}

Adanya sebuah paradigma yang berkembang di masyarakat bahwa proses belajar itu identik dengan buku dan menulis, secara tidak langsung telah mematikan kreatifitas tenaga pendidik kita selama ini untuk mengeksplorasi system pengajaran yang dinamis dan efektif. Salah satu penyebab kurangnya kiat guru untuk membangun sebuah hubungan interaktif dalam Kegiatan Belajar Mengajar (KBM) adalah kurangnya pengetahuan guru tentang pengembangan dan kegunaan media pembelajaran alternatif.

Menurut Wibawa dan Mukti (1993:

8), media dapat digunakan dalam proses belajar mengajar dengan dua cara, yaitu sebagai alat bantu mengajar dan sebagai media yang digunakan sendiri oleh anak. Media yang dipakai sebagai alat bantu mengajar disebut dependent media. Sedangkan media belajar yang dapat digunakan oleh anak dalam kegiatan belajar mandiri disebut independent media. Sementara itu, Angkowo dan Kosasih (Musfiqon, 2012: 32), berpendapat bahwa salah satu fungsi media pembelajaran adalah sebagai alat bantu pembelajaran yang ikut mempengaruhi situasi, kondisi dan lingkungan belajar dalam rangka mencapai tujuan pembelajaran yang telah diciptakan dan didesain oleh guru.

Media sumber belajar adalah alat bantu yang berguna dalam kegiatan belajar mengajar. Alat bantu dapat mewakili sesuatu yang tidak dapat disampaikan guru melalui kata-kata atau kalimat. Kesulitan anak memahami konsep dan prinsip tertentu dapat diatasi dengan bantuan alat bantu. Bahkan alat bantu diakui dapat melahirkan umpan balik yang baik dari anak didik. Dengan memanfaatkan taktik alat bantu yang mudah diterima, guru dapat menggairahkan minat belajar anak. Melalui permainan-permainan tradisional sederhana dapat menjadi sumber inspirasi dalam merancang sebuah media pembelajaran.

Media snader game adalah modifikasi dari permainan ular tangga, - dan merupakan salah satu alat penyampai materi kepada anak. Media tidak hanya dipahami sebagai alat peraga, tetapi juga sebagai pembawa informasi atau pesan pengajaran kepada peserta didik. Dengan adanya media snader game, pembelajaran akan lebih menarik, interaktif, dan menyenangkan sehingga secara tidak langsung kualitas pembelajaran dapat ditingkatkan ke arah yang lebih baik. Selain itu, pembelajaran dapat dilakukan dan dimana saja sesuai dengan yang diinginkan. Dengan kata lain, dengan adanya media snader game, proses pembelajaran akan berjalan lebih maksimal.

\section{Sejarah Snader Game}

Ular tangga adalah game yang ditemukan dan dimainkan oleh orangorang India sejak dahulu kala. Di India populer dengan nama Moksha Patamu yang ditemukan oleh guru spiritual hindu. Permainan ini disebut "leela" dan mencerminkan kesadaran hindu di sekitar kehidupan sehari-hari. Nama lainnya 
adalah "Tangga Keselamatan" yang lalu dibawa ke Victoria Inggris di mana versi barunya telah dibuat dan diperkenalkan oleh John Jacques di tahun 1892. Masuk ke Amerika oleh seorang pembuat mainan bernama Milton Bradley ditahun 1943 yang diberi nama "Snakes $n$ Ladder" yang artinya "Ular Tangga" (http:/hafismuaddab.wordress.com/2012/0 5/22/sejarah-permainan-ular-tangg/).

Permainan ular tangga menjadi bagian dari permainan di Indonesia meskipun tidak ada data yang lengkap mengenai kapan munculnya permainan tersebut. Pada zaman dulu, banyaknya anak-anak Indonesia yang bermain ular tangga membuat permaian ini menjadi sangat populer di masyarakat. Permainan ini ringan, sederhana, mendidik, menghibur dan sangat berinteraktif jika dimainkan bersama-sama.

Menurut

(hhttp:/id.wikipedia.org/wiki/ular-tangga), ular tangga adalah permainan papan untuk anak-anak yang dimainkan oleh dua orang atau lebih. Papan permainan dibagi dalam kotak-kotak kecil dan di beberapa kotak digambar sejumlah "tangga" atau "ular" yang menghubungkannya dengan kotak lain. Pada permainan ular tangga, media permainan adalah sebuah papan atau karton bergambar kotak-kotak biasanya berukuran $10 \times 10$ kotak. Tiap kotak diberi nomor urut mulai dari nomor 1 dari sudut kiri bawah sampai nomor 10 di sudut kanan bawah, lalu dari kanan ke kiri mulai nomor 11 baris kedua sampai 20 dan seterusnya sampai 100 di sudut kiri atas. Kotak-kotak tertentu berisi gambar yang mengandung pesan atau perbuatan. Ada pesan atau perbuatan baik, dan ada yang buruk. Pesan atau perbuatan baik biasanya diganjar dengan kenaikan ke kotak yang lebih tinggi lewat tangga, sedangkan pesan atau perbuatan yang buruk dihukum dengan penurunkan ke kotak yang lebih rendah melewati ular, sehingga dinamakan ular tangga.

\section{Pengertian Snader Game}

Menurut Jatmika (2012: 59), ular tangga adalah permainan papan untuk anak-anak, yang dimainkan oleh dua orang atau lebih. Papan permainan ini dibagi dalam kotak-kotak kecil, dan beberapa kotak digambarkan sejumlah "tangga" atau "ular" sebagai penghubung anatara kotak satu dengan yang lainnya.

Menurut

situs (hhttp:/id.wikipedia.org/wiki/ular-tangga), ular tangga merupakan permainan anakanak berbentuk papan yang dimainkan oleh dua orang atau lebih. Papan permainan dibagi dalam kotak-kotak kecil, sejumlah tangga atau ular digambar dibeberapa kotak yang menghubungkan dengan kotak lain

Berikut adalah beberapa aturan yang harus dipenuhi dalam permainan ular tangga agar mendapat hasil yang maksimal yaitu:

1. Setiap pemain dimulai pada bidak yang terdapat di pojok kiri bawah.

2. Dadu dilempar secara bergantian, kemudian lihatlah angka yang muncul pada dadu.

3. Bidak dapat dijalankan sesuai dengan jumlah mata dadu yang muncul.

4. Bila pemain mendarat di ujung sebuah tangga, pemain dapat langsung naik ke ujung tangga yang lain. Bila mendarat di kotak dengan ular, ia harus turun ke kotak di ujung bawah ular tersebut.

5. Pemenang adalah pemain pertama yang mencapai kotak terakhir.

6. Biasanya, jika seorang pemain mendapatkan angka 6 dari dadu, ia mendapat satu kali tambahan giliran. Bila tidak, maka giliran akan jatuh kepada pemain selanjutnya.

Papan permainan ular tangga dapat dimodifikasi menjadi media pembelajaran. Modifikasi dapat dilakukan dengan cara mengganti peraturan permainan. Giliran bermain dan jumlah langkah yang akan dimainkan ditentukan menggunakan lemparan dadu. Tujuan permainan adalah bagaimana mencapai kotak nomor 100 secepat mungkin. 


\section{Manfaat Snader Game}

Kita mengetahui bahwa permainan ular tangga adalah salah satu jenis permainan tradisional yang mendunia. Permainan ini tidak hanya berlaku di negara kita saja, tetapi juga di berbagai negara lain di dunia. Permainan ini merupakan jenis permainan kelompok, melibatkan beberapa orang dan tidak dapat digunakan secara individu. Secara psikologis, ular tangga terbukti dapat meningkatkan kemampuan anak-anak untuk berinteraksi dengan kehidupan sosial.

Dalam http://www.ayahbunda.co.id dijelaskan bahwa media permainan ular tangga memiliki beberapa manfaat diantaranya adalah:

1. Mengenal kalah dan menang

2. Belajar bekerja sama dan menunggu giliran

3. Mengembangkan imajinasi dan mengingat peraturan permainan

4. Merangsang anak belajar pramatematika yaitu saat menghitung langkah pada permainan ular tangga dan menghitung titik-titik yang terdapat pada dadu.

5. Belajar memecahkan masalah

Sejalan dengan pendapat Jatmika

(2012: 60), permainan ular tangga memiliki beberapa manfaat bagi anak, diantaranya sebagai berikut:

1. Merangsang anak untuk belajar matematika

Yaitu saat menghitung langkah pada permainan ular tangga, dan menghitung titik-titik yang terdapat pada dadu.

2. Mengenalkan bentuk warna dasar pada anak

Dari permainan ini, anak dapat mengenal ragam atau variasi bentuk warna. Ada benda berbentuk kotak, segi empat, dan bulat dengan beragam warna, biru, merah, hijau, dan lainnya

3. Mengenal kalah menang

Ketika bermain ular tangga anak bisa belajar bekerjasama, dan giliran bermain. Ia mampu berimajinasi dan mengingat peraturan permainan yang diwujudkan dalam langkah-langkah permainan. Keasyikan sebuah permainan baginya justru terletak pada peraturannya.

4. Mengasah kemampuan kognitif pada anak

Yaitu dengan mengajarkan sportivitas untuk mengakui kemenangan teman bermain. Selain itu, ia juga konsistensi dalam mengikuti aturan yang telah ditetapkan. Dari permainan ini pula, anak belajar memecahkan masalah, bekerja sama, dan menunggu giliran.

Snader game menekankan kompetisi, menang, atau kalah. Dari permainan ini anak belajar mengatasi ketegangan, apakah akan menang, atau kalah. Dari permainan ini pula anak tahu belajar memecahkan masalah, belajar bekerjasama, dan menunggu giliran. Dengan media snader game ini guru dapat menghemat waktu untuk menjelaskan secara detail bab tertentu yang perlu dijelaskan kembali secara struktural. Selain itu, anak juga dapat dengan mudah memahami apa yang disampaikan oleh guru melalui media ini karena anak tidak merasa terbebani dengan pengulangan unit tertentu. Pembelajaran yang melibatkan kecenderungan anak-anak untuk bermain jauh lebih efektif karena anak merasa lebih santai. Bagi anak-anak belajar sambil bermain adalah hal penting.

\section{Langkah-langkah Penggunaan Media Snader Game}

Ada beberapa aturan dalam penggunaan media permainan ular tangga menurut pendapat Jatmika (2012: 59) diantaranya adalah:

1. Setiap pemain dimulai pada bidak yang terdapat di pojok kiri bawah.

2. Dadu dilempar secara bergiliran, kemudian lihatlah angka yang muncul pada dadu.

3. Bidak dapat dijalankan sesuai jumlah mata dadu yang muncul.

4. Bila pemain mendarat di ujung bawah sebuah tangga, pemain dapat langsung naik ke ujung tangga yang lain. Bila mendarat di kotak dengan ular, ia harus 
turun ke kotak di ujung bawah ular tersebut.

5. Pemenang adalah pemain pertama yang mencapai kotak terakhir.

6. Biasanya, jika seorang pemain mendapatkan angka 6 dari dadu, ia mendapat satu kali tambahan giliran. Bila tidak, maka giliran akan jatuh kepada pemain selanjutnya.

Pada penelitian ini langkahlangkah penggunaan media snader game memiliki perbedaan aturan yang sedikit berbeda, namun pada dasarnya langkah dan aturannya sama, yang membedakan dengan langkah-langkah snader game pada umumnya karena papan permainan yang dirancang khusus oleh peneliti dengan ukuran papan permainan berukuran $3 \mathrm{~m} \times 4 \mathrm{~m}$, yang terdiri atas kotak-kotak yang berjumlah 26 buah sesuai dengan jumlah alfabet, masingmasing kotak berukuran $50 \mathrm{~cm} \times 50 \mathrm{~cm}$, terbuat dari bahan plastik flexy dan dadu terbuat dari kain flanel berwarna. Sedangkan bidak yang digunakan adalah anak yang mengikuti snader game ini.

Berikut adalah langkah-langkah penggunaan media snader game dalam penelitian ini diantaranya:

1. Semua pemain memulai permainan dari petak nomor 1 huruf a dan berakhir pada petak nomor 26 huruf $\mathrm{z}$.

2. Terdapat beberapa jumlah ular dan tangga papan permainan, terletak pada petak tertentu.

3. Terdapat satu dadu yang digunakan

4. Bidak yang digunakan adalah anak yang bermain dalam snader game

5. Panjang ular dan tangga bermacammacam

6. Ekor ular dapat memindahkan bidak pemain untuk mundur beberapa petak sesuai dengan gambar ular

7. Sedangkan gambar tangga dapat memindahkan bidak pemain maju beberapa petak

8. Sebagian dari gambar ular dan tangga adalah pendek, dan hanya sedikit tangga yang panjang.
9. Untuk menentukan siapa yang mendapat giliran bermain pertama, dilakukan dengan cara hompimpah oleh setiap pemain.

10. Selanjutnya dilanjutkan dengan suit oleh dua pemain yang terakhir.

11. Setelah mengetahui urutan pemain pertama sampai terakhir, para pemain berdiri pada posisi mulai (start) sesuai urutan masing-masing.

12. Kemudian pemain pertama melempar dadu dan melangkah di atas kotak sesuai jumlah mata dadu yang keluar.

13. Boleh terdapat lebih dari satu pemain pada suatu petak.

14. Jika pemain melangkah dan berakhir pada petak yang bergambar ekor ular, maka pemain tersebut harus turun sampai pada petak yang ditunjuk oleh kepala ular tersebut

15. Jika pemain melangkah dan berakhir pada petak bergambar kaki tangga, maka pemain tersebut berhak maju sampai pada petak yang ditunjuk oleh puncak dari tangga tersebut

16. Pemenang dari permainan ini adalah pemain yang pertama kali berhasil mencapai finish petak nomor 26 huruf $\mathrm{z}$

\section{Penggunaan Media Snader Game Untuk Meningkatkan Kemampuan Membaca Permulaan}

Di Playgroup ataupun di Taman Kanak-Kanak kegiatan pengembangan meliputi seluruh aspek pengembangan anak, yaitu kognitif, sosial, emosional, moral, bahasa, seni, dan fisik-motorik. Guru berperan, bertugas, dan bertanggung jawab sebagai perencana, pelaksana, dan penilai. Peran, tugas, dan tanggung jawab yang harus guru kembangkan untuk seluruh aspek perkembangan anak, termasuk juga dalam mengembangkan kemampuan pembaca permulaan anak di Playgroup, Taman Penitipan Anak, dan Taman Kanak-Kanak. Guru memiliki peranan yang sangat penting dalam mengembangkan berbagai jenis pembelajaran bahasa khususnya membaca 
permulaan yang berkualitas. Guru harus mampu merancang pembelajaran bahasa yang dapat mendorong pencapain kompetensi bahasa. Bahwa kegiatan pembelajaran bahasa khususnya membaca permulaan selain melatih kemampuan berpikir logis dan abstrak, juga harus melatih daya ingat anak. Beberapa kiat yang dapat dilakukan guru untuk meningkatkan kemampuan anak dalam mengingat adalah sebagai berikut:

a. Pelajaran harus bermakna bagi anak,

b. Kegiatan pembelajaran harus mampu menghubungkan antara berbagai pengetahuan yang telah dimiliki anak dengan berbagai topik yang diajarkan dalam pembelajaran membaca permulaan.

Media pembelajaran adalah segala sesuatu yang dapat menyalurkan pesan dan dapat merangsang pikiran, perasaan, dan kemauan untuk terjadinya proses belajar. Dengan media anak mendapat banyak informasi sehingga materi akan semakin jelas dan mudah dimengerti. Selain itu, media juga dapat mengurangi keterbatasan guru atau buku dan meningkatkan daya tarik terhadap materi yang sedang diajarkan sehingga anak lebih berminat untuk belajar.

Dalam pembelajaran membaca permulaan digunakan media yaitu agar dapat menjembatani antara konsep-konsep membaca yang abstrak menjadi lebih kongkrit, sehingga anak dapat memahami bacaan yang disajikan oleh guru. Penggunaan media snader game sebagai media pembelajaran dapat digunakan sebagai salah satu alternatif untuk dapat mengembangkan kemampuan membaca permulaan. Penggunaan media snader game dilakukan oleh dua orang atau lebih. Penggunaan media snader game pada saat kegiatan pembuka sehingga anak pada waktu kegiatan dapat belajar seraya bermain secara bersama-sama yang dilakukan di dalam kelas atau di luar kelas. Dalam kegiatan ini penggunaan media snader game anak praktek langsung, sehingga anak menjadi aktif dalam pembelajaran. Dalam pembelajarannya media snader game dijadikan sebagai alat permainan sehingga anak tidak merasa sedang belajar. Misalnya: anak harus menghitung, dan membaca

Kemampuan membaca yang dapat dikembangkan adalah pemahaman terhadap gambar, huruf alfabetik, dan kata. Guru dapat menggunakan media snader game, yang digunakan dalam pembelajaran membaca anak usia dini yang merupakan permainan yang disukai anak-anak, karena cara memainkannya yang sangat mudah dan menarik. Keterampilan berbahasa yang dapat distimulasi melalui permainan ini misalnya mengenal huruf, kata, gambar, kosa kata naik, maju mundur, ke atas-ke bawah, dan sebagainya. Keterampilan sosial yang dilatih dalam snader game ini di antaranya kemauan mengikuti dan mematuhi aturan permainan, bermain secara bergiliran. Keterampilan kognitif matematika yang terstimulasi yaitu menyebutkan urutan bilangan, mengenal lambang bilangan, dan konsep bilangan.

dampak penggunaan media membawa pembelajaran. Media yang di gunakan dalam penelitian ini adalah snader game. Beberapa keunggulan media snader game yaitu:

1. Media snader game memungkinkan anak berinteraksi langsung antara anak dengan benda-benda disekitarnya

2. Media snader game dapat membangkitkan motivasi belajar anak

3. Media snader game dapat menciptakan suasana pembelajaran yang menyenangkan

4. Media snader game lebih membangkitkan motivasi dan merangsang anak untuk belajar

5. Media snader game dapat menstimulasi aspek perkembangan kognitif, bahasa, dan sosial

Penggunaan snader game dalam proses pembelajaran merupakan cara yang efektif apabila dilihat dari beberapa keunggulan media snader game. 
Penggunaan media snader game mempunyai beberapa kelemahan yaitu:

1. Penggunaan media snader game memerlukan banyak waktu untuk menjelaskan kepada anak.

2. Snader game tidak dapat mengembangkan semua materi pembelajaran.

3. Kurangnya pemahaman aturan permainan oleh anak dapat

- menimbulkan kericuhan.

4. Bagi anak yang tidak menguasai materi dengan baik akan mengalami kesulitan dalam bermain.

\section{Penutup}

Media snader games umumnya hanya digunakan untuk permainan fisik dan berhitung. Namun snader games dapat dikreasi menjadi media yang mampu mengembangkan berbagai aspek termasuk bahasa yaitu untuk pengenalan membaca permulaan. Diperlukan kreativitas guru agar media snader games dapat menjadi alternatif media yang menarik dan dapat membantu guru dalam mengoptimalkan perkembangan anak.

\section{Daftar Rujukan}

Ahmad Susanto. (2011). Perkembangan Anak Usia Dini Pengantar dalam Berbagai Aspeknya. Jakarta: Kencana

Arsyad. (2006). Media Pembelajaran. Jakarta: Raja Grafindo Persada.

Basuki W. \& Farida M. (1993). Media Pengajaran. Depdikbud Dirjen Dikti Pembinaan Tenaga kependidikan.

Evi Hasim. (2008). Penggunaan Media Kata Bergambar dalam upaya Meningkatkan Kualitas Pembelajaran Membaca dan Menulis Permulaan di Kelas 1 Sekolah Dasar, Jurnal Penelitian dan Pendidikan, Vol. 5 No. 2 Juli 2008, Hal 78-87.

Farida Rahim. (2008). Pengajaran Membaca di Sekolah Dasar. Jakarta: PT Bumi Aksara

Hurlock, E. B. (1991). Perkembangan Anak Jilid 1 (Alih Bahasa: Meitasari Tjandrasa dan Muslichach Zarkasih). Jakarta: Erlangga.

Joko Sutrisno. (2008). Peran Multimedia dalam Pembelajaran dan Gaya BelajarSiswa.Diaksesdari http://www.erlangga.co.id/artikel/ pendidikan/365-example-pagesandmenu-links.html. pada tanggal 23 Juni 2013. Jam 19.00 WIB.

Maimunah Hasan. (2010). Pendidikan Anak Usia Dini. Jogjakarta: Diva Press

Mulyono Abdurrahman. (2012). Anak Berkesulitan Belajar. Jakarta: Rineka Cipta.

Musfiqon. (2012). Pengembangan Media dan Sumber Pembelajaran. Jakarta: Prestasi Pustakarya

Poerwadarminta. (1999). Kamus Besar Bahasa Indonesia-Edisi Kedua, Cetakan Kesepuluh. Jakarta: Balai Pustaka.

Slamet Suyanto. (2005). Dasar-Dasar Pendidikan Anak Usia Dini. Yogyakarta: Hikayat.

Soemiarti Padmonodewo. (2003). Pendidikan Anak Prasekolah. Jakarta: Rineka Cipta

Tadkiroatun Musfiroh. (2009). Menumbuhkan Baca-Tulis Anak Usia Dini. Jakarta: Gramedia Widiasarana 
Undang-Undang Sisdiknas. (2003). Tentang Pendidikan Anak Usia Dini. Jakarta: Sinar Grafika.

http://www.ayahbunda.co.id/Artikel/Terba ru/Terbaru/bermain.ular.tangga. belajar.pahami.aturan/001/007/339/ 3.pada tanggal 20 Februari 2013. Jam 11.00 WIB.

(http:/hafismuaddab.wordpress.com/2012/ 05/22/sejarah-permainan-ulartangga/).pada tanggal 21 Februari 2013.Jam 16.00 WIB. (hhttp:/id.wikipedia.org/wiki/ulartangga).pada tanggal 21 Februari 2013.Jam 17.30 WIB.

http://www.paudni.kemdikbud.go.id/wpcontent/uploads/2013/07/2.JuknisKelompok-Bermain.pdf.pada tanggal 7 September 2013.Jam 13.00 WIB

http://auliamakro.wordpress.com/pendidik an-anak-usia-dini/hakikatkelompok-bermain/.pada tanggal 7 September 2013. Jam 13.30 WIB 